\title{
PEMBELAJARAN TEMATIK PADA BIDANG STUDI PKn KELAS IV DI SEKOLAH DASAR MENDONGAN PLAYEN GUNUNG KIDUL YOGYAKARTA TAHUN PELAJARAN 2014/2015
}

\author{
Oleh: \\ Slamet* \\ Universitas Cokroaminoto Yogyakarta
}

\begin{abstract}
Abstrak
Penelitian ini bertujuan untuk mengetahui perencanaan pembelajaran tematik dan proses pembelajaran tematik serta evaluasi pembelajaran tematik di kelas IV Sekolah Dasar Negeri Mendongan Playen Gunungkidul. Penelitian ini termasuk dalam penelitian diskriptif dengan pendekatan kualitatif. Pada penelitian ini yang menjadi subyek adalah guru kelas IV serta siswa kelas IV Sekolah Dasar Negeri Mendongan Playen Gunungkidul tahun 2014/2015 dengan jumlah siswa 16 ( $\mathrm{L}=11$ dan $\mathrm{P}=5$ ). Simpulan yang diperoleh dari penelitian ini, di antaranya: (1) Guru kelas IV SD Negeri Mendongan Playen Gunungkidul belum melakukan perencanaan tematik sebagaimana mestinya seperti tidak merumuskan tema untuk pembelajaran selama satu semester tapi sudah melakukan perencanaan pembelajaran secara umum seperti pembuatan RPP dan lain-lain; (2) Evaluasi yang dilaksanakan di sesuaikan dengan konsep KTSP yaitu evaluasi dari seluruh aspek yakni aspek kognitif, afektif dan psikomotorik; dan (3) Hambatan-hambatan yang dialami guru kelas IV SD Negeri Mendongan Playen Gunungkidul yaitu kesulitan dalam pengelolaan kelas, kesulitan dalam penyatuan tema serta belum bisa melaksanakan pembelajaran tematik yang sesungguhnya yaitu mengintegralkan bidang studi dalam satu tema.
\end{abstract}

Kata kunci: Pembelajaran, pembelajaran tematik, tema.

\section{Pendahuluan}

Pendidikan yang berorientasi pada siswa seyoganya mengutamakan belajar cara-cara belajar (learning how to learn) dan bukan sekedar mempelajari materi-materi. Ini berarti bahwa pendidikan yang demokratis harus memberlakukan beragam metode yang menggali kemampuan siswa untuk berperan secara aktif dengan mengakui perbedaan kemampuan intelektual, kecepatan, belajar, sikap, sifat dan minatnya. Menurut Conny Semiawan (2000:21-22) bahwa pengajar masih berperan sebagai aktor utama di kelas. Sehingga siswa secara dominan bersifat pasif, hanya mendengarkan, mencatat penjelasan guru sehingga siswa tidak menjadi komunikatif dan tidak memiliki keterampilan menyatakan diri. Meskipun siswa memahami apa yang mereka 
dengar tapi jarang terjadi pengembangan mandiri berdasarkan aktivitas kreatif dalam konteks tipe pembelajar yang bersifat eksploratif.

Permasalahan lain yang perlu diperhatikan dalam pendidikan di Indonesia adalah isi kurikulum yang diajarkan sering bersifat teoritis abstrak (Conny Semiawan;2000:22), sedangkan kenyataan kehidupan menuntut keterlibatan langsung dalam berbagai perkara. Guru kebanyakan memaparkan fakta-fakta dan pengetahuan ataupun hukum tertentu kepada siswa tapi tidak mengaitkannya dengan pengalaman empiris yang akan diamati untuk diinterpretasikan dan disimpulkan sebagai suatu pemikiran yang bersifat hipotesis.

Salah satu ruang kreatif dalam implementasi KTSP adalah pembelajaran tematik, yaitu sebuah model pembelajaran yang menekankan pada pemaknaan pengalaman belajar siswa, dengan memadukan antara mata pelajaran yang satu dengan mata pelajaran yang lain dalam satu tema yang mengangkat tema-tema aktual dalam kehidupan sehari-hari. Ini merupakan upaya untuk menyiasati kurikulum yang padat dan muatan kegiatan yang tinggi dengan berbagai macam mata pelajaran, pembelajaran tematik menjadi pilihan yang tepat bagi sekolah. Metode ini tidak mengesampingkan kurikulum nasional, melainkan sebagai upaya untuk menerapkan kurikulum 2006 dengan cara yang menarik dan mudah sesuai dengan infrastruktur dan instansi pengembang yang terlatih, kreatif dan fasilitas yang memadai. (Sutirjo dan Sri Istuti Mamik, 2004:3).

Alasan mendasar mengenai model belajar ini adalah, pertama, bahwa kenyataan empiris dalam kehidupan sehari-hari tidak satupun fenomena alam yang berdiri sendiri, namun bersifat kompleks dan terpadu, artinya satu fenomena terkait antara satu dengan yang lainnya. Kedua, perkembangan IPTEK yang begitu pesat dan permasalahan ilmiah ini membutuhkan penyikapan yang realistis. Jika setiap materi dari perkembangan permasalahan yang pesat dimunculkan dalam satu bidang mata pelajaran sendiri-sendiri, tidak terbayangkan betapa banyak beban studi yang harus diterima. Oleh karena itu tujuan model pembelajaran ini adalah untuk mengakomodasikan perkembangan IPTEK serta permasalahan yang begitu kompleks dalam masyarakat sehingga anak tidak terpisah dengan kenyataan hidup. (Sutirjo dan Sri Istuti Mamik;2005:4).

Upaya kreatif ini, utamanya yang berkaitan dengan kurikulum 2006 KTSP ditegaskan bahwa kegiatan pembelajaran yang telah disiapkan secara nasional menjadi acuan sekolah untuk 
dikembangkan sesuai dengan kebutuhan, situasi dan kondisi lingkungan masing-masing, namun kompetensi dasar harus tetap tercapai. "Hal mendasar yang harus diperhatikan oleh guru adalah bahwa proses pembelajaran yang akan dilakukan adalah untuk memperkaya pengalaman belajar siswa. Sedangkan tujuan dasar pembelajaran tematik adalah untuk efisiensi waktu, beban materi, metode penggunaan sumber belajar yang tematik, sehingga dapat mencapai kompetensi yang tepat dan efisien.” (Sutirjo dan Sri Istuti Mamik;2005:12).

Oleh karena itu, untuk menerapkan suatu konsep model pembelajaran tematik ini, diperlukan suatu kerangka yang melukiskan prosedur yang sistematis dalam mengorganisasikan pengalaman belajar untuk mencapai tujuan belajar tertentu, dan berfungsi sebagai pedoman dalam merancang pembelajaran dan para pengajar dalam merencanakan dan melaksanakan aktivitas belajar mengajar. Dengan demikian aktivitas belajar mengajar benar-benar tertata dan merupakan suatu kegiatan yang sistematis.

Salah satu lembaga pendidikan yang telah mencoba menggunakan metode ini adalah Sekolah Dasar Negeri Mendongan Kecamatan Playen Gunungkidul. Penerapan metode ini terutama pada kelas rendah (kelas I - IV). Menjadi sesuatu yang menarik peneliti, untuk kemudian menggali lebih jauh aspek-aspek yang berkait dengan pelaksanaannya.

Persoalan pelaksanaan model pembelajaran tematik pada prinsipnya terletak pada aspekaspek sistem pelaksanaan. Maka yang dimaksud "model pembelajaran”, kerangka konseptual yang melukiskan prosedur sistematis dalam mengorganisasikan pengalaman belajar untuk mencapai tujuan belajar tertentu, dan berfungsi sebagai pedoman bagi perancang pembelajaran dan para pengajar dalam merencanakan dan melaksanakan aktivitas belajar mengajar. (Udin Saparudin, 1997:78-79).

Dengan demikian, dari konsep metode pembelajaran tematik ini, ada beberapa hal mendasar yang harus diperhatikan, pertama, prosedur pengorganisasian pengalaman belajar yang sesuai dengan kebutuhan siswa di Sekolah Dasar Negeri Mendongan Kecamatan Playen Gunungkidul. Kedua, perlunya kreatifitas pemilihan metode belajar, sistem pengelolaan kelas dan sistem evaluasi yang sesuai dengan tujuan pembelajaran. Ketiga, perlunya pemanfaatan sumber belajar dengan memanfaatkan infrastruktur dan lingkungan yang tersedia, dan keempat, mengidentifikasi faktor-faktor pendukung dan penghambat sebagai upaya optimalisasi pelaksanaan konsep pembelajaran tematik. 
Rumusan masalah pada penelitian ini adalah: (1) Bagaimana perencanaan dan proses pembelajaran tematik di kelas IV Sekolah Dasar Negeri Mendongan Kecamatan Playen Gunungkidul?; (2) Bagaimana evaluasi pembelajaran tematik di kelas IV Sekolah Dasar Negeri Mendongan Playen Gunungkidul? Tujuan penelitian ini adalah untuk mengetahui (1) Perencanaan pembelajaran tematik dan proses pembelajaran tematik di kelas IV Sekolah Dasar Negeri Mendongan Playen Gunungkidul; (2) Evaluasi pembelajaran tematik di kelas IV Sekolah Dasar Negeri Mendongan Playen Gunungkidul.

Manfaat dari penelitian ini adalah untuk mengembangkan teori/bidang ilmu strategi belajar mengajar dan perencanaan mengajar, digunakan sebagai bahan masukkan untuk meningkatkan kualitas pembelajaran tematik, digunakan sebagai bahan masukan untuk mengoptimalkan pelaksanaan pembelajaran tematik.

\section{Metode Penelitian}

Penelitian ini termasuk dalam penelitian diskriptif dengan pendekatan kualitatif. Menurut Sumadi Suryasubrata (2003:76), penelitian deskriptif adalah penelitian yang bermaksud untuk membuat diskripsi mengenai situasi-situasi atau kejadian-kejadian. Data yang dikumpulkan semata-mata bersifat deskriptif sehingga tidak bermaksud mencari penjelasan, mengenai hipotesis, membuat prediksi, maupun mencari implikasi. Jadi dalam penelitian ini akan mengumpulkan data deskriptif yang diperoleh dari pengumpulan data yang nantinya dituangkan dalam bentuk laporan dan uraian berupa kata-kata.

Penelitian ini dilaksanakan di Sekolah Dasar Negeri Mendongan Playen Gunungkidul yang merupakan sekolah dasar yang melaksanakan pembelajaran tematik untuk kelas 1V. Dalam penelitian ini peneliti mengambil kelas IV karena siswa sudah belajar dengan pembelajaran tematik. Penelitian ini akan dilakukan sekitar 2 bulan yaitu bulan Desember 2014 sampai bulan Februari 2015 yang digunakan untuk mengumpulkan data. Pada penelitian ini yang menjadi subyek adalah guru kelas IV serta siswa kelas IV Sekolah Dasar Negeri Mendongan Playen Gunungkidul tahun 2014/2015 dengan jumlah siswa 16 ( $\mathrm{L}=11$ dan P=5 ).

Pengumpulan data pada penelitian ini dilakukan dengan 3 teknik, yaitu wawancara, observasi dan dokumentasi sebagai pendukung. Wawancara dapat dipakai untuk melengkapi data yang diperoleh melalui observasi. Pada penelitian ini wawancara akan dilaksanakan sebelum dan 
sesudah observasi dilaksanakan. Wawancara dilaksanakan terhadap guru dan siswa kelas IV SD Mendongan Playen Gunungkidul. Mengingat keterbatasan indera manusia dalam pengamatan, maka sebelum mengadakan observasi sebaiknya mempunyai konsep lebih dahulu, yaitu konsep tentang hal-hal apa saja yang diperlukan untuk diamati, bagian-bagian mana yang diperlukan, seberapa banyak yang dibutuhkan. Observasi dalam penelitian ini akan dilaksanakan sejak awal hingga akhir penelitian. Dalam penelitian ini, dokumen yang dimaksud adalah data tentang perencanaan pembelajaran yang telah disusun oleh guru. Dengan metode ini yang diamati bukan benda hidup tetap benda mati. Dalam menggunakan metode ini peneliti memegang checklist untuk mencari variabel yang sudah ditentukan.

Dalam penelitian ini peneliti mempunyai kedudukan sebagai instrumen yang terjun langsung ke lapangan dalam pengambilan data dengan metode wawancara, observasi dan dokumentasi. Dalam penelitian ini analisa data dimaksudkan untuk mengorganisasikan data yang telah terkumpul dari hasil wawancara dan observasi. Pekerjaan analisa data dalam hal ini adalah mengurutkan, mengelompokkan, memberikan kode dan mengategorikannya. Semua data dikelompokkan dengan menggunakan acuan analisis non statistik yang konkret.

1. Reduksi data

Tahap ini merupakan kegiatan pemilihan data, penyederhanaan data serta transformasi data kasar dari catatan pengamatan. Hasil reduksi berupa uraian singkat yang telah digolongkan dalam satu kegiatan tertentu.

2. Display data

Data-data yang telah dikumpulkan, dituangkan ke dalam matrik, bagan, grafik dan uraian deskriptif seperlunya sehingga data itu dapat adanya hubungan secara keseluruhan serta mudah dibaca dan dipahami.

3. Mengambil kesimpulan/verifikasi data

Kesimpulan diambil sejak penelitian dimulai hingga selesainya penelitian sehingga diperoleh kesimpulan yang dijamin kredibilitasnya dan efektivitasnya.

Teknik keabsahan data pada penelitian ini menggunakan triangulasi. Triangulasi adalah teknik pemeriksaan keabsahan data yang memanfaatkan sesuatu yang lain di luar data itu untuk keperluan pengecekan atau sebagai pembanding terhadap data itu. (Moleong; 2000:178). 
Triangulasi yang digunakan dalam penelitian ini adalah triangulasi sumber, yang membandingkan dan mengecek balik derajat kepercayaan suatu informasi yang diperoleh melalui waktu dan alat yang berbeda dalam metode kualitatif, yang dapat dicapai dengan jalan membandingkan antara pengamatan dengan data hasil wawancara dan membandingkan hasil wawancara dengan isi dokumen yang berkaitan dengan variabel penelitian.

\section{Pembahasan}

1. Pelaksanaan Pembelajaran Tematik di kelas IV Sekolah Dasar Negeri Mendongan Playen Gunungkidul.

Setting kelas IV Sekolah Dasar Negeri Mendongan Playen Gunungkidul diatur seperti kelas biasa. Tempat duduk siswa dibuat 4 saff. Satu meja untuk dua orang siswa dengan 2 kursi. Dua saff dikanan di tempati oleh siswa putra dan dua saff kiri ditempati oleh siswa putri.

Di dinding kelas ditempeli hasil karya siswa, gambar-gambar beserta bahasa Inggris, gambar presiden dan wakil presiden di depan kelas. Jadwal piket siswa serta gambar-gambar lain yang mendukung.

Aktivitas selanjutnya setelah guru melakukan perencanaan pembelajaran adalah pelaksanaan atau realisasi dari perencanaan yang telah dibuat guru untuk diterapkan di kelas. Aktivitas tersebut terdiri dari membuka pelajaran, menyampaikan materi serta menutup pelajaran. Kegiatan aktivitas ini tidak terlepas dari komponen-komponen pembelajaran seperti siswa, metode, media dan lain-lain.

Membuka pembelajaran adalah upaya untuk mengondisikan siswa agar siap belajar. Banyak hal yang dilakukan dalam membuka pelajaran seperti menyampaikan tujuan yang hendak dicapai, memberikan masalah-masalah pokok yang hendak dipelajari atau hal-hal lain yang bisa menarik perhatian siswa untuk mengikuti pelajaran.

Menurut Soetomo (1994:106) membuka pelajaran adalah kegiatan yang dilakukan guru dalam pembelajaran untuk menciptakan suasana yang menjadikan siswa siap mental dan menimbulkan perhatian siswa terpusat pada hal-hal yang akan dipelajari.

Berdasarkan pengamatan penelitian di kelas Sekolah Dasar Mendongan Playen Gunungkidul membuka pelajaran pada jam pertama dan jam-jam pelajaran selanjutnya berbeda. Baik guru $\mathrm{M}$ dan guru $\mathrm{Y}$, pada saat jam pelajaran pertama membuka pelajaran dengan mengucapkan salam kepada siswa dan membaca doa mau belajar. Setelah itu biasanya siswa 
diajak tepuk irama dan bernyanyi. Guru juga biasanya menanyakan pengalaman siswa seperti pada saat tema Hewan dan Tumbuhan di Lingkungan Rumahku, guru memulai dengan menanyakan hal-hal seputar pribadi siswa dan kegiatan siswa sebelum berangkat sekolah dan diselipi dengan pesan-pesan moral. Seperti, menanyakan siapa yang hari ini bangun pagi dan sholat atau menanyakan siapa yang membantu orang tua sebelum berangkat ke sekolah dan pekerjaan apa yang dilakukan. Pemanasan apersepsi yang dilakukan di awal pembelajaran sebaiknya dimulai dengan hal-hal yang diketahui dan dipahami oleh siswa. Apersepsi juga bisa dilakukan dengan menyampaikan bahan ajar yang menarik dan berguna bagi siswa, hal ini membangkitkan motivasi siswa.

Pada umumnya Guru kelas di Sekolah Dasar jarang menyampaikan tujuan pembelajaran kepada siswa dan jarang menjelaskan apa saja yang akan mereka pelajari. Padahal menurut Soetomo (1993:40-41), dengan menyampaikan tujuan pembelajaran terlebih dahulu, siswa akan merasa tertarik pada materi yang akan disampaikan guru, karena siswa tahu apa yang diharapkan dari dirinya oleh guru dan siswa tahu untuk apa dirinya belajar. Dengan demikian anak tidak meraba-raba maksud guru menerangkan materi itu. Selain itu memberitahukan tujuan juga berguna untuk guru karena menjadi pedoman guru untuk mengarahkan semua kegiatan pembelajaran agar tercapai tujuan yang telah ditetapkan. Setelah itu, guru membagi siswa ke dalam kelompok-kelompok berdasarkan shaf-shaf tempat duduk siswa. Sedangkan pada jam pelajaran selanjutnya pelajaran dibuka dengan menertibkan siswa, kemudian diajak bernyanyi. Lalu guru membagi siswa ke dalam kelompok-kelompok. Nama kelompok ditentukan sendiri oleh siswa berdasarkan tema saat itu. Pada saat tema Kejadian sehari-hari, nama kelompok adalah nama kegiatan sehari-hari yang biasa dilakukan siswa seperti mandi, sholat, bermain, belajar dan lain-lain. Setiap pelajaran nama-nama kelompok selalu diubah, jika pelajaran bahasa Jawa maka nama kelompok dalam bahasa Jawa. Seringkali dalam pemilihan nama kelompok terjadi keributan di kelas sehingga guru perlu mengkondisikan siswa kembali. Untuk mengkondisikan siswa, perlu waktu yang tidak sedikit agar mereka siap belajar. Bahkan terkadang guru sama sekali tidak bisa mengkondisikan mereka sehingga pembelajaran tidak bisa berjalan secara optimal.

Setelah siswa dalam kondisi siap untuk belajar pada saat itu, guru mulai mengawali materi. Dalam menyampaikan pelajaran, guru M lebih sering menggunakan media, terutama 
untuk mata pelajaran sains dan matematika. Media yang digunakan sangat sederhana. Seperti, media kartu angka yang dibuat sendiri dengan menggunakan kertas karton. Selain itu juga menggunakan sedotan, karet gelang, lidi, korek api dan manik-manik. Media-media ini digunakan pada saat siswa belajar tentang bilangan. Guru membagikan ke tiap-tiap kelompok benda-benda tersebut. Kelompok satu mendapat sedotan, kelompok 2 mendapat karet. Kelompok tiga mendapat manik-manik dan kelompok empat mendapat sedotan. Kemudian siswa diberi tugas untuk mengelompokkan benda yang telah dibagikan sesuai dengan bilangan loncat yang mereka pelajari, misalnya loncat 5. Siswa mengelompokkan benda tersebut 5-5 sampai benda tersebut habis atau sisa. Kemudian mereka menghitung jumlah benda tersebut. Biasanya guru juga menggunakan media secara refleks tanpa disiapkan terlebih dahulu. Misalnya pada saat membahas tentang benda padat dan benda cair, untuk memberi contoh benda padat dan benda cair guru menggunakan air minum yang dibawa siswa atau benda-benda di sekitar siswa.

Guru kelas IV Sekolah Dasar Negeri Mendongan Playen Gunungkidul dalam pembelajaran walaupun masih bersifat sangat sederhana. Penggunaan medianya tergantung dengan materi yang disampaikan. Sebelum kegiatan belajar mengajar dimulai guru menyiapkan media yang akan digunakan. Media yang digunakan adalah benda-benda yang ada di sekitar siswa. Selain itu guru juga menggunakan lingkungan sebagai sumber belajar bagi siswa.

Dalam proses pembelajaran yang berkedudukan sebagai pengirim pesan adalah guru dan siswa sebagai penerima pesan. Guru menggunakan media dalam pembelajaran untuk mempermudah menyampaikan materi kepada siswa. Dalam menyampaikan materi, guru M dan guru Y menggunakan bahasa yang komunikatif dan mudah dimengerti oleh siswa. Terkadang guru secara tidak sengaja menggunakan kata-kata yang belum dimengerti siswa dan siswa langsung menanyakan arti dari kata tersebut, seperti, ketika guru M memberikan nasehat bahwa siswa harus konsisten dengan peraturan-peraturan yang telah disepakati bersama di kelas. Salah satu siswa langsung bertanya arti kata konsisten tersebut. Penyampaian materi selalu diawali dengan hal-hal kontekstual atau yang berhubungan dekat dengan siswa. Pada saat menyampaikan pelajaran bahasa Indonesia dengan tema kegiatan sehari-hari, guru Y terlebih dahulu menanyakan kepada siswa siapa yang sering membantu orang tua di rumah dan pekerjaan apa yang sering mereka lakukan. Pembelajaran tematik selalu bertumpu pada masalah-masalah kontekstual dan terintegrasi dengan lingkungan. 
Kegiatan belajar di luar kelas antara lain siswa mencari data, bermain sambil belajar dan lain-lain. Salah satu hal yang membedakan pembelajaran konvensional dengan pembelajaran tematik adalah pemanfaatan lingkungan sebagai sumber belajar. Pada pembelajaran konvensional atau pembelajaran yang selama ini terjadi, menggunakan kelas sebagai satu-satunya tempat belajar. Sedangkan dalam pembelajaran tematik, menggunakan tempat belajar secara bervariasi di dalam dan di luar kelas sehingga pembelajaran yang berlangsung tidak membosankan. Pada saat pelajaran PKn yang membahas tentang guru Y menggunakan halaman sekolah sebagai tempat belajar siswa. Kegiatan belajar dikemas dalam bentuk permainan. Guru Y menyebar kartu-kartu di halaman sekolah, ada yang ditempel di pohon ataupun di dinding sekolah. Kartukartu tersebut terdiri dari kartu yang bertuliskan dan kartu yang merupakan terjemahan dari. Siswa yang telah dibagi ke dalam kelompok diminta untuk mencari kartu-kartu tersebut dan menyesuaikan dengan artinya masing-masing setelah itu kartu-kartu tersebut ditempel di papan tulis berdasarkan kelompok masing-masing.

Selain menyampaikan materi, guru selalu menyampaikan pesan-pesan moral kepada siswa baik itu terkait dengan materi maupun tidak. Misalnya ada siswa yang tidak mau masuk ke kelompoknya karena tidak suka dengan salah satu temannya. Guru menjelaskan bahwa kita tidak boleh memilih teman karena Allah SWT Maha Besar telah menciptakan kita tidak sama satu sama lain baik dengan kelebihan maupun dengan kekurangan masing-masing. Siswa juga dilibatkan dalam penyelesaian masalah. Jika ada yang bertengkar guru menanyakan bagaimana penyelesaiannya dan siswa yang bertengkar tersebut diminta untuk memaafkan. Guru M menjelaskan, "Siswa tidak semata-mata mempelajari ilmu-ilmu umum atau aspek kognitif saja tapi dengan pesan-pesan moral ini atau tausiyah ini diharapkan siswa tidak hanya pintar dari segi intelektual saja tapi juga memiliki moral atau akhlak yang baik." Inilah salah satu bentuk keterpaduan pembelajaran di SD Negeri Mendongan Playen Gunungkidul, guru tidak hanya bertanggung jawab menyampaikan hal-hal yang berkaitan dengan aspek kognitif saja tapi guru juga menyampaikan hal-hal yang berkaitan dengan aspek kognitif saja tapi guru juga menyampaikan hal-hal yang berkaitan dengan aspek afektif dan dikaitkan dengan akhlak Islami. Jika materi tidak tersampaikan atau tujuan yang telah ditetapkan tidak tercapai maka guru akan mengulang materi tersebut hingga sebagian besar siswa bisa memahaminya. Guru M mengatakan, “tidak apa-apa tidak tercapai karena RPP sekedar rencana kalo' manusia bisa 
mengubah dan materi tersebut tetap diulang," Sedangkan guru Y mengatakan, "materi tetap diulang sampai sebagaian besar siswa mengerti." Berkaitan dengan masalah waktu, guru telah mengalokasikan waktu cadangan jadi tidak khawatir kekurangan waktu jika mengulang materi hingga sebagian siswa memahaminya. Tapi pengulangan materi ini juga ada batasannya. Hal ini bisa diamati dari dokumentasi, guru mengalokasikan waktu cadangan untuk setiap mata pelajaran, selain itu hal ini juga dipertegas oleh guru Y, "Saya tidak khawatir kekurangan waktu karena sudah dialokasikan waktu cadangan." Tapi pengulangan materi ini juga ada batasannya dan biasanya diulang sekilas sebelum materi yang baru disampaikan. Seperti yang diungkapkan oleh guru M, “....materi-materi yang kurang itu saya ulang bersamaan dengan materi baru.”

Berdasarkan prinsip belajar tuntas, seorang peserta dididik dipandang tuntas belajar jika ia mampu menyelesaikan, menguasai kompetensi atau mencapai tujuan pembelajaran minimal 65 $\%$ dari seluruh tujuan pembelajaran. Sedangkan jika keberhasilan kelas dilihat dari jumlah peserta didik yang mampu menyelesaikan atau mencapai minimal $65 \%$ dan sekurang-kurangnya $85 \%$ dari jumlah peserta didik yang ada di kelas tersebut (Mulyasa, 2003:99). Guru maupun sekolah perlu memberikan perlakuan khusus kepada siswa yang mengalami kesulitan belajar melalui kegiatan remidial, sedangkan peserta didik yang kemajuan belajarnya baik, diberikan kesempatan untuk mempertahankan kecepatan belajarnya melalui kegiatan pengayaan. (Mulyasa, 2003:99).

Dalam pembelajaran, siswa menjadi pusat dalam kegiatan belajar mengajar. Siswa selalu dilibatkan dalam setiap kegiatan belajar, sehingga siswa menjadi aktif. Ciri pembelajaran tematik yang efektif adalah aktif dan berpusat pada siswa. Guru hanya memberikan ruang kondusif dan memfasilitasi tumbuhnya pengalaman-pengalaman yang berarti bagi siswa dengan menempatkan siswa sebagai subjek dalam belajar. Peranan guru dalam penyajian materi pembelajaran dan dalam mengelola proses pembelajaran dalam rangka menciptakan suasana belajar yang lebih melibatkan siswa untuk aktif dalam melatih berpikir logis, kritis, dan analitis serta mengembangkan potensi yang ada pada diri siswa.

Pada pembelajaran konvensional, pembelajaran didominasi oleh guru. Jadi guru masih sebagai aktor di kelas. Guru berperan sebagai penyampai informasi sebanyak-banyaknya kepada siswa. Siswa lebih banyak mendengar, mencatat dan menghafal informasi. Siswa tidak banyak terlibat dalam pembelajaran serta tidak diberi peluang untuk mencari dan menemukan sesuatu, sehingga anak kehilangan sesuatu yaitu pengalaman pembelajaran alamiah langsung. Siswa kelas 
IV Sekolah Dasar Negeri Mendongan Playen Gunungkidul Yogyakarta berani ketika disuruh gurunya maju baik untuk bermain peran maupun mengerjakan soal-soal bahkan terkadang sampai rebutan hingga kelas menjadi ribut. Keributan ini terkadang menganggu kegiatan pembelajaran. Penjelasan dari guru sulit untuk didengar oleh siswa yang lain. Dan biasanya jika sudah ribut, siswa sulit dikondisikan. Keributan ini bisa disebabkan oleh siswa yang berbicara dengan suara keras di kelas, ada yang keluar kelas dan ada yang jalan-jalan di kelas. Selain itu siswa juga diberi kebebasan dan berani mengemukakan ide, pendapat dan menjawab pertanyaan-pertanyaan dari guru bahkan siswa juga tidak sungkan untuk bertanya jika mereka tidak mengerti apa yang dijelaskan oleh guru.

Dalam pembelajaran guru harus sering mengkondisikan siswa. Guru tidak pernah memarahi ataupun membentak siswa. Jika ada siswa dalam kondisi seperti ini, guru akan mendekati mereka lalu mengajak mereka untuk belajar kembali. Jika hal tidak bisa juga, guru akan mengadakan lomba "anteng-antengan" bagi kelompok yang anggota kelompoknya tenang dan duduk tertib maka nilai kelompoknya akan ditambah dan sebaliknya jika ada anggota kelompoknya yang tidak tenang atau masih ribut maka nilai kelompoknya akan dikurangi atau tidak dikasih nilai. Cara seperti ini cukup ampuh, siswa yang masih jalan di kelas biasanya langsung duduk ditempat masing-masing. Semua siswa menjadi tenang. Dan guru bisa melanjutkan pelajaran kembali. Tapi biasanya kelas akan menjadi ribut kembali apalagi jika ada tanya jawab maka guru seringkali mengkondisikan siswa sehingga waktu belajar banyak yang terpotong untuk mengkondisikan mereka.

Pertengkaran antar siswa juga sering terjadi di kelas dan hal ini juga terjadi di saat pembelajaran berlangsung, sehingga guru harus mendamaikan keduanya, biasanya agar tidak mengganggu siswa yang lain, siswa yang bertengkar tersebut dibawa ke kantor. Hal ini sedikit banyak mempengaruhi situasi kondusif belajar yang telah tercipta.

Pengelolaan kelas yang dilakukan guru ada yang kalanya tidak sepenuhnya bisa mengkondisikan siswa untuk memiliki mental belajar. Pada awalnya siswa bisa kembali tenang dan mengikuti pelajaran tapi beberapa saat kemudian siswa kembali ribut. Seringkali usaha yang dilakukan guru gagal karena siswa sudah sangat tidak bisa lagi untuk dikendalikan. Kondisi siswa seperti ini mengganggu pelaksanaan pembelajaran sehingga pembelajaran tidak berjalan dengan optimal dan tujuan yang telah ditetapkan tidak tercapai. 
Penggunaan media, metode yang bervariasi pun kadangkala tidak mampu untuk menarik perhatian siswa. Walaupun kondisi kelas seperti ini, tapi masih ada siswa yang benar-benar belajar, mengerjakan setiap tugas yang diberikan guru serta menyimak setiap penjelasan dari guru. Guru perlu memberikan teguran secara tegas dan jelas kepada siswa yang menunjukkan perilaku yang mengganggu atau menyimpang tapi harus menghindari ejekan dan peringatan yang kasar dan menyakitkan. (Abdul Majid, 2005:120).

Keberhasilan dalam pembelajaran juga salah satunya ditentukan oleh metode yang digunakan guru dalam penyampaian materi. Metode yang digunakan dalam pembelajaran di kelas 2 Sekolah Dasar Negeri Mendongan Playen Gunungkidul Yogyakarta divariasikan dan disesuaikan dengan materi yang sedang dipelajari agar siswa tidak pbosan. Hal ini dipertegas oleh guru Y, "kreativitas guru sangat dituntut, metode, media, sarana dan strategi di variasi tapi itu semua butuh pemikiran ekstra. Kalo' anak bosan ini, diganti yang lain.” Adapun metode-metode yang digunakan adalah :

\section{1) Ceramah}

Berdasarkan pengamatan peneliti, metode ceramah digunakan oleh guru $\mathrm{M}$ dan guru $\mathrm{Y}$ di awal pembelajaran untuk menjelaskan materi. Tapi terkadang metode ini juga digunakan ditengah-tengah pada saat guru menjelaskan kembali materi jika ada siswa yang belum mengerti.

2) Tanya jawab

Metode ini sering dipadukan dengan metode-metode lain. Hal ini untuk melihat pemahaman siswa serta melatih siswa untuk berfikir kreatif dan melibatkan siswa secara aktif. Dalam menjawab pertanyaan guru, siswa sangat antusias bahkan kelas sampai menjadi ribut.

3) Bermain peran

Bermain peran lebih sering digunakan untuk mata pelajaran Sosial dan Pendidikan Kewarganegaraan. Bermain peran masih dibimbing oleh guru. Guru menunjuk beberapa siswa, kemudian guru membagi peran kepada siswa yang ditunjuk. Guru membisikkan sesuatu kepada salah satu siswa berdasarkan peran masing-masing, siswa yang telah dibisikkan oleh guru tersebut kemudian mengucapkan sesuatu berdasar apa yang telah ia dengar dari gurunya, begitulah seterusnya. Terkadang untuk menarik perhatian siswa, yang bermain peran adalah guru M dan guru Y. Setelah bermain peran selesai, guru memberikan pertanyaan-pertanyaan kepada 
siswa seputar cerita atau nilai-nilai yang terkandung pada cerita tersebut yang telah diperankan oleh beberapa siswa.

4) Pemberian tugas

Guru sering memberikan tugas kepada siswa, baik itu PR ataupun tugas-tugas lainnya. Ketika guru selesai menjelaskan materi, guru memberikan tugas-tugas kepada siswa, seperti mencari data sesuai dengan materi yang dipelajari ataupun mengerjakan latihan-latihan di buku paket.

Pada saat mengerjakan tugas ini seringnya tidak semua siswa mengerjakan. Mereka biasanya bermain-main, mengobrol bahkan ada yang bermain di luar kelas.

\section{5) Demonstrasi dan Eksperimen}

Metode demonstrasi dan eksperimen sering digunakan pada mata pelajaran Sains . Seperti pada mata pelajaran Sains dengan bahasan perubahan wujud benda. Guru M melakukan demonstrasi dengan memanaskan gula pasir hingga mencair. Ini untuk menjelaskan kepada siswa tentang perubahan wujud benda dari padat ke cair. Selain itu dilakukan juga eksperimen. Sebelumnya siswa dibagi menjadi 5 kelompok dan setiap anggota kelompok mendapat tabel observasi. Di kelas, dibagi menjadi 5 pos. Pos I terdapat lilin dan korek api. Siswa disuruh melakukan sesuatu yang dapat merubah lilin dari bentuk semula. Kemudian siswa diminta mengamati lilin setelah terbakar api dan setelah dingin. Di pos 2, diletakkan karet dan kapur. Siswa diminta merubah bentuk benda-benda tersebut. Di pos 3 ada segelas air dan piring kosong. Siswa diminta melakukan sesuatu agar air berubah bentuk di pos 4 terdapat es batu yang tengahnya di beri garam. Siswa diminta mengamati apa yang terjadi dengan es batu tersebut terutama yang dibagian yang ada garamnya. Di pos 5 terdapat cincau yang telah membeku. Proses pembuatan cincau ini disaksikan oleh siswa juga mereka terlibat dalam pembuatannya. Setiap kelompok bergiliran mengunjungi pos-pos ini. Di setiap pos mereka melakukan apa yang telah ditugaskan. Setelah semua pos mereka kunjungi, mereka secara individual mengisi lembar tabel observasi yang telah dibagikan guru.

6) Cerita

Untuk menyampaikan materi agar menarik perhatian siswa, guru menggunakan metode cerita. Metode ini sering digunakan untuk mata pelajaran-pelajaran selain matematika. Dalam bercerita, guru menyesuaikan mimik dan suaranya sesuai dengan isi cerita. Siswa terkadang 
tertawa atau tersenyum mendengarkan cerita dari guru tapi mereka antusias untuk mendengarkan cerita tersebut. Setelah itu, guru melontarkan pertanyaan kepada siswa berkaitan dengan isi cerita. 7) Pengamatan

Pengamatan dilakukan terhadap benda-benda atau hal-hal yang ada disekitar siswa hingga lingkungan sekolah. Seperti pada mata pelajaran Sains dengan bahasan benda mati dan benda hidup. Setelah guru menjelaskan ciri-ciri dan beberapa contoh benda mati dan benda hidup, siswa diberi tugas untuk mengamati benda-benda di sekitar kelas ataupun lingkungan sekolah. Kemudian menuliskan apa saja yang termasuk benda mati dan benda hidup serta ciri-ciri dari benda tersebut. Jawaban siswa beraneka ragam sesuai dengan benda-benda yang dilihat dan diamati mereka.

Agar siswa semangat belajar, guru juga memberikan motivasi kepada siswa. Pemberian motivasi ini dilakukan dengan memberikan pujian, hadiah ataupun nasehat-nasehat. Seperti yang dijelaskan oleh guru Y "Saya memberi motivasi, bisa disela-sela pembelajaran atau pada saat kegiatan pembelajaran berlangsung. Bentuknya bisa dengan pujian, hadiah ataupun nasehatnasehat." Pemberian motivasi juga dilakukan dengan sedikit ancaman seperti yang diungkapkan oleh guru M “.... Saya beri mereka dua pilihan, mau ikut pelajaran di kelas 2 atau mengerjakan tugasnya di kelas 1V". Hal ini dilakukan guru M apabila ada siswa yang tidak mau mengikuti pelajaran. Sebelum memberikan dua pilihan itu, guru M terlebih dulu mendekati dan menanyakan secara baik-baik kepada siswa tersebut alasan mengapa ia tidak mau mengikuti pelajaran.

Pembelajaran tematik menunjang penciptaan pembelajaran aktif dan dapat memotivasi siswa. Motivasi dapat tercipta jika guru dapat meyakinkan siswa akan kegunaan materi pelajaran bagi kehidupan siswa secara nyata. Selain itu guru dapat menciptakan situasi belajar sehingga materi pelajaran selalu tampak menarik dan tidak membosankan. Seyogyanya guru memiliki sensitivitas yang tinggi untuk segera merefleksi dan memperkaya metodologi pembelajaran yang lebih tepat guna dan menyenangkan.

Tahap akhir yang dilakukan guru dalam pembelajaran adalah menutup pelajaran yaitu dengan membuat kesimpulan atas materi-materi yang dipelajari. Guru kelas IV Sekolah Dasar Negeri selalu membuat kesimpulan terhadap materi-materi yang telah disampaikan. Jika kondisi siswa sudah tidak memungkinkan lagi untuk belajar maka guru tidak membuat kesimpulan saat itu. Menyimpulkan materi yang telah dibahas biasanya juga dilakukan guru pada saat siswa mau 
pulang yang dilakukan sebelum berdoa. Guru menanyakan kepada siswa apa saja yang telah mereka pelajari pada setiap mata pelajaran hari itu. Setelah itu guru menyimpulkan kembali sebagai penegasan dari jawaban siswa. Tapi jika saat itu kondisi sudah tidak memungkinkan maka guru tidak membuat kesimpulan terhadap mata pelajaran yang telah dipelajari dari awal sampai akhir. Padahal hal ini penting dilakukan, agar siswa merasa ikut terlibat dalam menyimpulkan materi yang akhirnya memungkinkan siswa untuk belajar lagi setelah sampai di rumah. Kegiatan selanjutnya adalah membaca do’a penutup mencari ilmu.

2. Pelaksanaan Evaluasi Pembelajaran Tematik di kelas IV Sekolah Dasar Negeri Mendongan Kecamatan Playen Gunungkidul

Evaluasi pembelajaran yang dilakukan oleh guru kelas IV SDN Mendongan evaluasi proses dan hasil yang mencakup 3 aspek yaitu aspek kognitif, afektif dan psikomotorik.

Evaluasi dari sisi kognitif adalah siswa bisa menjawab pertanyaan ataupun soal-soal yang diberikan guru baik melalui lisan ataupun secara tertulis dan ini termasuk evaluasi hasil. Evaluasi hasil juga bisa berupa produk akhir dari karya siswa. Sedangkan dari sisi afektif dan psikomotor lebih banyak masuk dalam evaluasi proses. Kesungguhan dan keaktifan siswa dalam belajar termasuk dalam evaluasi ini.

Bentuk evaluasi yang dilakukan adalah ulangan harian, mid semester, ulangan umum, tugas-tugas dan unjuk kerja. Dari ulangan harian bisa melihat sejauh mana pemahaman siswa terhadap materi yang telah dipelajari. Jika ternyata banyak siswa yang tidak bisa atau salah dalam menjawab soal maka guru akan mengulang kembali ulangan harian itu dengan terlebih dulu mengulang materi tersebut kembali. Guru M mengatakan “...pada akhirnya saya harus menentukan batas kapan saya mereview. Saya akan mengulang ulangan harian itu jika $30 \%$ anak tidak mencapai target. Nanti jika sudah diulang jumlahnya mengecil maka saya teruskan materinya dan saya rencanakan materi-materi yang kurang itu saya ulang bersamaan dengan pemberian materi baru". Mendekati akhir semester guru melakukan pengayaan terhadap materimateri yang telah dipelajari, hal ini tercantum dalam dokumentasi, guru mengalokasikan waktu untuk pengayaan materi serta perbaikan nilai per mata pelajaran.

Hasil dokumentasi memaparkan bahwa evaluasi telah direncanakan oleh guru, yaitu :

1) Ulangan harian dengan alokasi yang berbeda-beda tiap mata pelajaran. 
2) Mid semester tiap mata pelajaran rata-rata 2-3 jam pelajaran per semester.

3) Tes hasil belajar semester I yang dilakukan setelah seluruh materi dipelajari.

Berdasarkan wawancara dengan guru diketahui bahwa ketika tes tertulis ada siswa yang tidak bisa mengerjakan soal-soal padahal ketika latihan dan praktek di kelas siswa mengerti dan bisa mengerjakan soal-soal yang diberikan guru. Kesulitan siswa ini ternyata pada pemahaman soal karena ada beberapa siswa yang belum lancar membaca serta ketidaktelitian siswa dalam membaca soal, hal ini terlihat pada saat observasi. Ketika tanya jawab secara lisan atau praktek di kelas, siswa mampu menjawab pertanyaan guru dengan benar tapi ketika tes tertulis, siswa memerlukan waktu yang lebih untuk bisa menjawab seluruh soal dan itu pun masih bertanya kepada guru. Guru beberapa kali mengadakan ulangan harian perbaikan karena banyak siswa yang salah menjawab soal. Evaluasi yang dilakukan guru kelas IV SD Negeri Mendongan Playen Gunungkidul. sesuai dengan evaluasi yang dirancang pada kurikulum Tingkat satuan Pendidikan

\section{Kesimpulan}

Dari pembahasan dan analisis data yang diperoleh tentang pelaksanaan pembelajaran tematik di kelas 1V SD Negeri Mendongan Playen Gunungkidul, maka dapat ditarik kesimpulan sebagai berikut:

1. Guru kelas IV SD Negeri Mendongan Playen Gunungkidul belum melakukan perencanaan tematik sebagaimana mestinya seperti tidak merumuskan tema untuk pembelajaran selama satu semester tapi sudah melakukan perencanaan pembelajaran secara umum seperti pembuatan RPP dan lain-lain. Pada prinsipnya pembelajaran tematik yang saat ini dilaksanakan di kelas 1V SD Negeri Mendongan Playen Gunungkidul masih memerlukan pengembangan-pengembangan seperti konsep pembelajaran tematik yang sesungguhnya.

Pelaksanaan pembelajaran tematik di kelas IV SD Negeri Mendongan Playen Gunungkidul masih memiliki kelemahan-kelemahan jika dibandingkan dengan konsep pembelajaran secara umum dan pembelajaran tematik pada khususnya. Dalam membuka pelajaran guru sudah melakukan dengan baik yaitu dengan apersepsi untuk mengkondisikan siswa agar siap belajar. Dalam menyampaikan materi guru menggunakan media walau bersifat sangat sederhana, variasi metode dan pemanfaatan lingkungan sekitar. Tapi terkadang kegiatan pembelajaran ini sering terkacaukan dengan keributan-keributan yang ditimbulkan siswa sehingga penjelasan dari guru 